\title{
Modern Bureautration Models
}

\author{
H. A. Jamaluddin \\ STISIP Muhammadiyah Sinjai, Sinjai, Indonesia \\ Email: ramlijamaluddin@yahoo.com
}

How to cite this paper: Jamaluddin, H.A. (2018) Modern Bureautration Models. Open Journal of Social Sciences, 6, 25-33. https://doi.org/10.4236/jss.2018.610003

Received: August 14, 2018

Accepted: October 15, 2018

Published: October 18, 2018

Copyright $\odot 2018$ by author and Scientific Research Publishing Inc. This work is licensed under the Creative Commons Attribution International License (CC BY 4.0).

http://creativecommons.org/licenses/by/4.0/

\begin{abstract}
The bureacracy service is very important by state and citizen to be studied which is comprehensive to see the condition of bureacracy service in Indonesia compared with Southern Asia states such as Malaysia, Singapore, Thailand, Brunei, Cambodja, Laos, Myanmar; they have different bureacracy services suitable with the interest of the state and citizen. For Indonesia, the bureacracy service is still the service decentralization; to be part of state and public, regent is interested with service, so it is difficult to get service standard which is ideal. The result of research concludes that the bureacracy service in Southern Asia namely Singapore applied modern bureacracy service which was oriented on happiness, pride and loyalty. The effectivity of government, new public management, new public service and modern bureacracy service, represent the important component which is needed in a government. The model of modern bureacracy service is oriented on service pattern which is simple, clear, safe, timely, transparent, efficient, economical, and equitable.
\end{abstract}

\section{Keywords}

New Public Management, New Public Service, Modern Bureacracy Service

\section{Introduction}

The success of a country is determined by the role of the bureaucracy it carries. That is why the bureaucracy controls the success of the country to be advanced or modern. One of the principles of advanced and modern bureaucracy is the applied bureaucratic service. Service is an essential element for the success of a bureaucracy in managing state governance and successful management of society.

The concept of modern bureaucracy is taking care of good governance and providing optimal service to society. The distinction between developed and developing countries is evident from the implementation of bureaucratic services. 
There is a tendency of bureaucracy service momentum in developed countries to be an absolute necessity to be implemented, in line with the government's openness and public demand for the best service, while for developing countries the demands of bureaucratic service are still controlled as a practical politicization for the state or government to implement practices that are disoriented with the public interest (Balley, 2006) [1].

The significance of the bureaucratic service to the state and society is a comprehensive study by looking at the conditions of Indonesia's bureaucratic service compared to Southeast Asian countries such as Malaysia, Singapore, Thailand, Brunei, Vietnam, Cambodia, Laos, Myanmar, having different bureaucratic services according to the interests of the state and society. Due to the existence of various differences of interest in the activities of bureaucracy services, today there are two important momentums in applying the bureaucratic service that are state service and public service.

In Indonesia, its bureaucratic service is still a pseudo-decentralized service, neither state-oriented nor public-oriented, tending to favor the services, making it difficult to obtain an ideal service standard.

The New Public Service (NPS) theory and New Public Management (NPM) theories of two actualizing theories for Indonesia and Southeast Asian countries have not been oriented to public service or service for the state. This is marked by the many services that do not comply with the principles of good governance. There is still a lot of collusion, nepotism and corruption in service activities. The presence of the state has not been able to provide the best service to the public and the state has not been able to manage the services according to the needs of its people (Keban, 2004) [2].

NPS theory applied by the government in several countries such as Indonesia and Southeast Asia, based on the phenomenon has not been in accordance with the expected target. Its realization reaches only $40.7 \%$ to $70.2 \%$. For Indonesia, the implementation of NPS done by the state to the ideal public has only reached $62.5 \%$ in the era of Joko Widodo Government, in comparison with the era of the previous presidential government. While Singapore and Malaysia ranked the application of NPS is better than Indonesia, for Singapore that is $70.2 \%$ and Malaysia is $68.1 \%$.

An indication of the application of good NPS cannot be separated from the NPM theory that can manage the bureaucracy and government organization in a planned, directed, implemented, organized and controlled to carry out management functions in providing the best service to the public. But the application of NPM-oriented implementation of the NPS has not been fully integrated, so the power of government bureaucracy is often contaminated by political policies that favor the status quo or unpopular policies to maintain the existence of power at the expense of public alignment (Cadwen, 2012) [3].

The importance of seeing modern bureaucratic services is inseparable from the concept of good governance and new public management concepts and new 
public service concepts combined into a unified concept of modern bureaucratic service called Modern Bueracration Service (MBS).

\section{Theoretical Assumptions}

According to Robbinson (2012) organizational effectiveness is very determining the concept of bureaucratic services appropriate competence, transparency, accountability, participation, law enforcement and social justice, so that became the basis in understanding the theory of government effectiveness. Robbinson stated that effective governance is actualized in its bureaucratic service.

The important thing to be actualized in the effectiveness of governance is how the government has competence, transparency, accountability, participation, law enforcement and social justice in providing bureaucratic services for state and public interest. On this basis, 8 principles of good governance under UNDP were established: 1) the government encourages the growth of public participation in determining service decisions; 2) the government provides a guarantee of law enforcement for the implementation of good service; 3) all service processes should be transparently institutionalized; 4) the government has high responsiveness in serving the public; 5) developing a public-oriented consensus of orientation; 6) provide effective and efficient services in accordance with the availability of facilities; 7) develop accountability of service accountability; and 8) develop an integrated service vision strategy between the interests of the state and society [4].

The need for bureaucratic services for a country should apply the NPM theory proposed by Osborne (2008) that the government operates a management function in accordance with service mechanisms and public demands. This theory, provides an interpretation that the development of a country is characterized by the government's share in carrying out the management function to regulate the government in order to ensure the realization of good service to the public. The application of this theory is more correlated with the NPS theory which in the momentum of bureaucratic service form is partisanship to the public.

The NPS theory proposed by Osborne (2008) that the best service is a public service. The realization of public service is to provide simple, clear and secure services, safe, open, efficient, economical, equitable justice and timeliness. This is a form of consensus of services needed by the public as important in realizing the success of the bureaucracy [5].

Development of government effectiveness theory that leads to the realization of good governance in accordance with the concept of NPM and NPS, then the transformation of modernization and globalization change encourages the creation of modern bureaucratic service. Modern bureaucratic service theory or Modern Bureacracy Service (MBS) is proposed by Gaster (2011) that good bureaucratic service is fun, pride and public loyalty [6]. That is, every service provided by the bureaucracy makes the public feel fulfilled all the demands and needs that make the public feel happy, who then feel proud of the services pro- 
vided and always perform services regularly as a manifestation of loyalty to the service received.

\section{Research Methods}

Research on modern bureaucratic service model using a qualitative descriptive research approach that explains the phenomenon studied. The data in this study consisted of: 1) primary data, that is data obtained from research results; 2) secondary data, i.e. data obtained from international journal referrals.

The data collection used in the framework of research is as follows: 1) international journals on modern bureaucratic services, 2) direct observation, i.e. researcher plunge directly into the field and observe directs the implementation of modern bureaucracy services for the state of Indonesia and compare it with other countries in Southeast Asia.

Data analysis used is a taxonomic analysis that is formed of analysis more detail and depth in discussing a theme or subject matter. Where the dominant or highlighted field needs to be traced in depth and in detail its internal structure.

\section{Analysis and Discussion}

\section{Picture of Bureaucratic Service}

Based on observations on the comparative analysis of bureaucratic service implementation in Southeast Asian countries, it is seen from four contexts: 1) the context of government bureaucracy; 2) the context of NPM; 3) NPS context; and 4) the context of SBM.

As shown in Figure 1 that bureaucracy implementation has been applied in Southeast Asian country, but its application is different but shows the trend of increasing from year to year. Where is Singapore's highest ranking government bureaucratic service trends in comparison with Malaysia, Indonesia and other Southeast Asian countries. The following graph shows data on the implementation of NPM in Southeast Asian Countries.

Referring to Figure 2 above shows that NPM has been applied in Southeast Asian countries. Apparently the percentage of its implementation varies from country to country and shows an upward trend year by year. The Singapore state shows the highest trend of NPM implementation in its government compared to Malaysia, Indonesia and other Southeast Asian countries.

Furthermore, the NPS deployment graph data for Southeast Asian countries is shown as follows:

As we see in Figure 3 shows that the application of NPS has been applied in Southeast Asian countries. Apparently the percentage of its implementation varies from country to country and shows an upward trend year by year. The Singapore state shows the highest trend of NPS implementation in its government compared to other Southeast Asian countries.

Hereinafter is shown graph data of application of MBS for Southeast Asian Country as follows: 


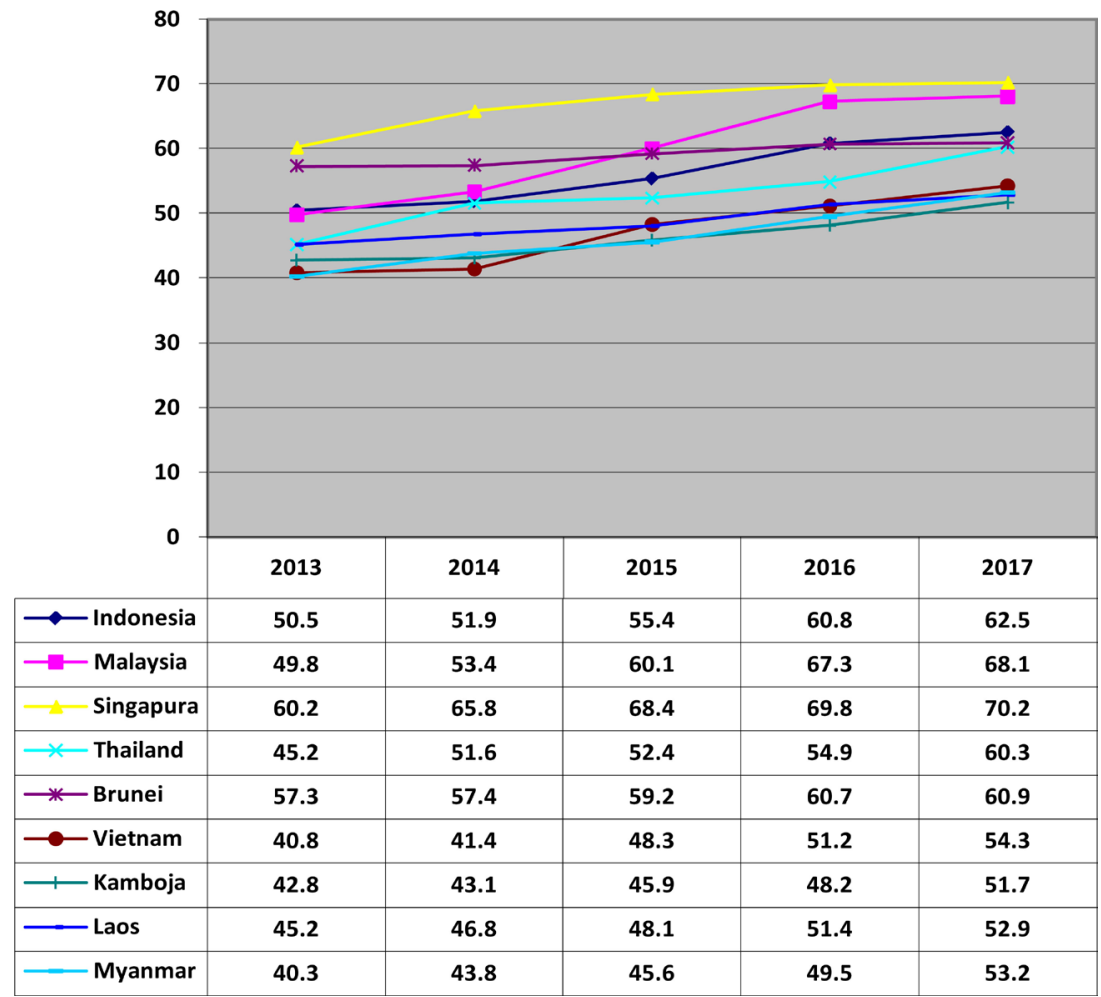

Source: Bureaucratic service implementation in Southeast Asian countries.

Figure 1. Graph of percentage of government services in Southeast Asian countries year 2013-2017 [7].

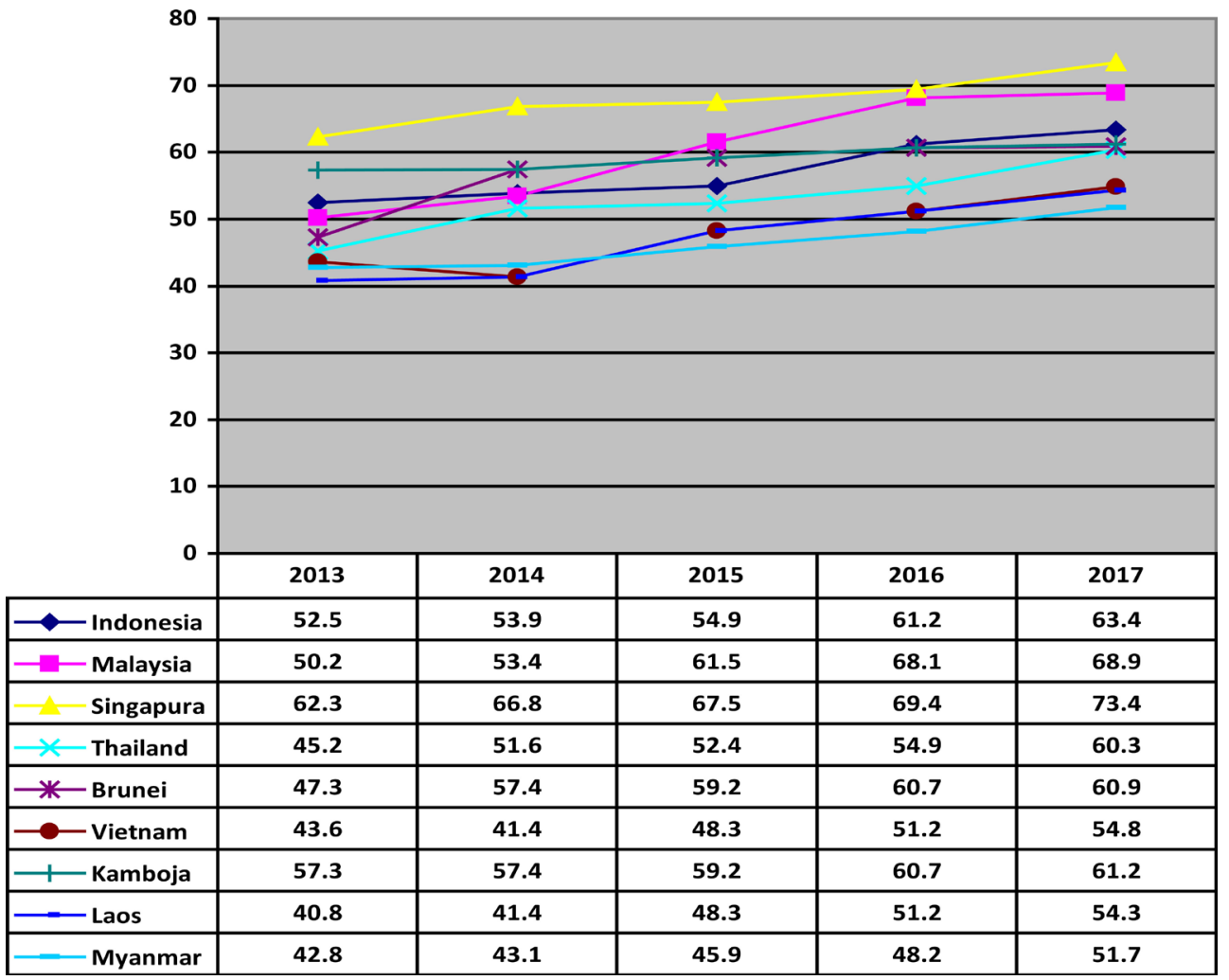

Source: Bureaucratic service implementation in Southeast Asian countries

Figure 2. Graph of percentage of NPM implementation in Southeast Asian countries year 2013-2017 [8]. 


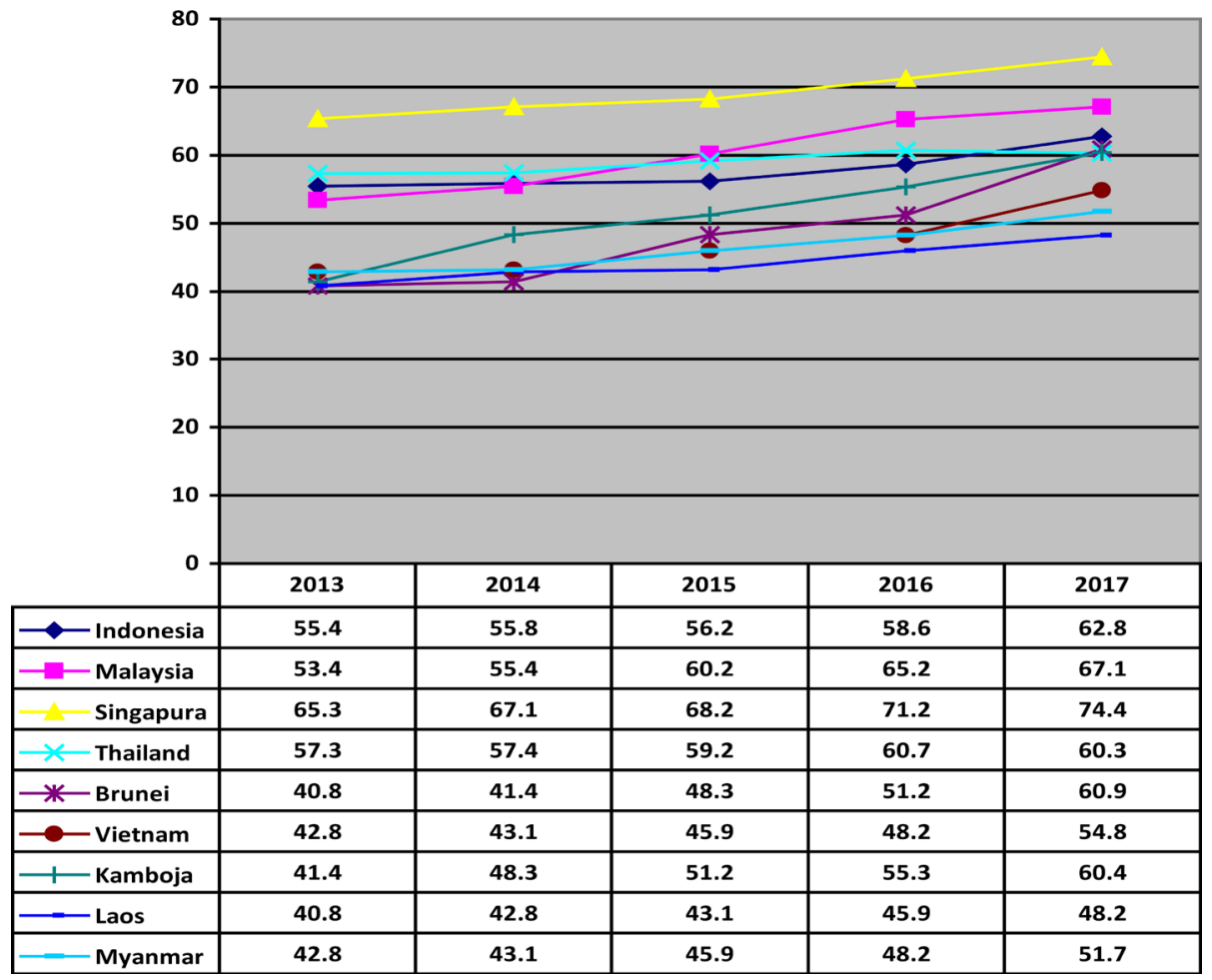

Source: Bureaucratic service implementation in Southeast Asian countries

Figure 3. Graph of percentage of NPS in Southeast Asian countries year 2013-2017.

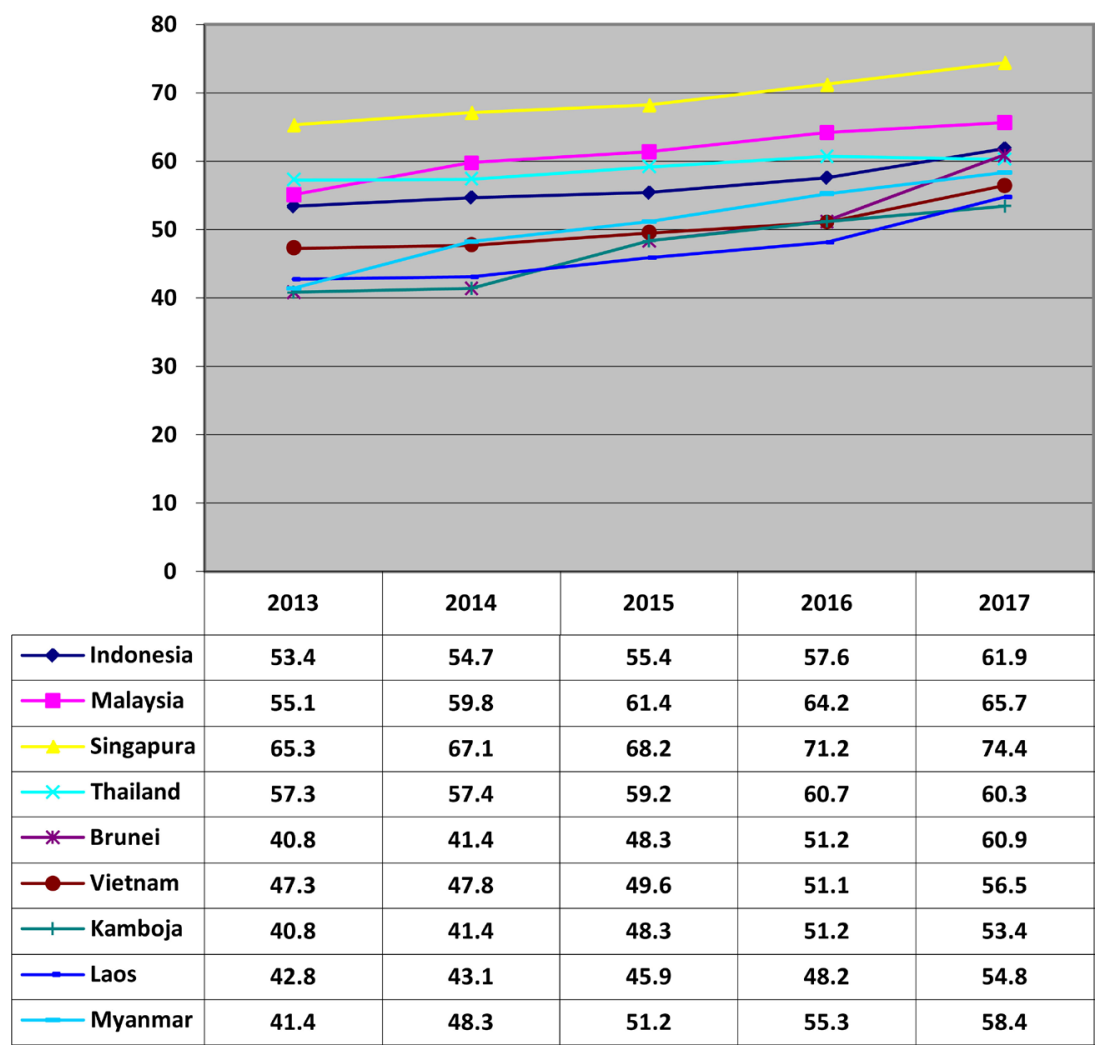

Source: Bureaucratic service implementation in Southeast Asian countries

Figure 4. Graph of percentage of MBS implementation in Southeast Asian countries year 2013-2017. 
Underlined Figure 4 shows that the application of SBM in the highest Southeast Asian country remains Singapore. This means that Singapore in applying modern bureaucracy services always pays attention to the alignment to the public, especially in meeting the level of fulfillment of pleasure in the sense of the realization of service satisfaction, fulfilling the pride of service in accordance with the orientation of excellent service and fostering the level of public loyalty to always do the service. Singapore can be an example in the application of modern bureaucratic services, so that the picture of government bureaucracy can be used as the best service model.

\section{System Relationships, Strategies and Management}

Actualization of modern bureaucracy service implementation cannot be separated from the relationship between system, strategy and management. A system is a series of service process processes undertaken by policy-makers or politicians (states) who are actualized by service providers to a citizen-oriented provider. Hasard (2012) argues that a good system is a system that brings state, provider and citizen as a whole in implementing the common goal of integrated services [9].

The existence of the actualization of bureaucratic services is a method or a strategic way in realizing the accessibility of the state, provider and society. The form of the strategy is a strategy of alignment, interests and luck. The strategy of alignment is a service orientation that is always oriented to the target of the provider and the community. The strategy of interest is the service orientation for the benefit of state stability and the prosperity of society. And luck strategy is a strategy that is used by all parties involved directly or indirectly get the benefits of easy service, fast, smooth and quality.

The importance of bureaucratic system and service strategy is applied to develop the concept of service management which is systematic and strategic. The concept of systematic service management is to perform services according to the mechanisms and rules that have been systematized in a device that is a link or network between government agencies and non government which is called e-government and e-company. More details are shown related relationships as follows:

Figure 5 shows how the relationship of system, strategy and management is needed in bureaucratic service activities. The better the system is applied, the strategy supports the development of better service management. Therefore,

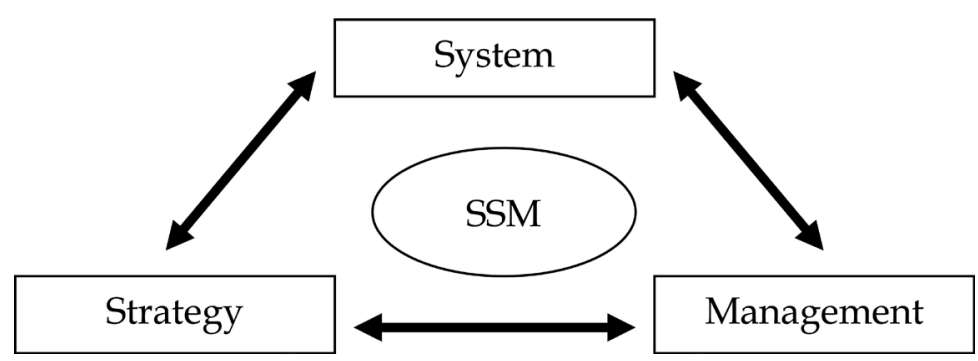

Source: Bureaucratic service implementation in Southeast Asian countries.

Figure 5. System relationships, strategy and management of bureaucratic services. 
these three components become an indispensable entity in realizing modern bureaucratic services.

\section{Modern Bureaucracy Service Model}

The modern bureaucratic service model is a model of the comparison of various forms of service applied in government bureaucracy. Broadly speaking, a service implemented within a country is taken on the basis of government and politician decisions in formulating a policy that must be implemented and evaluable. The implementer of a bureaucratic service policy is assigned to the institution or organization related to the service activities as the provider that runs the service in accordance with the system, strategy and service management with the operational standards of the maximal service implementation

The development of a bureaucratic service model created by the state and run by the provider of the service of each organization is dedicated to the community or citizen. A comprehensive and service-oriented bureaucracy is essential if the service is public on the part of a citizen. The consequence of the modern bureaucratic service model is the realization of pleasant service, pride and cultivation of loyalty from all related parties.

The following shows the model of the results of the development of modern bureaucratic services implemented by the governments of Southeast Asian countries, including in this case Indonesia as in the picture below:

Furthermore, as shown in Figure 6 that based on the modern bureaucratic service model, a proposition of premises is built. The proposition is "to realize a modern bureaucratic service based on an integrated service pattern", with the premise: 1) the state must ensure the best service pattern; 2) the provider embodies a quality service pattern; and 3) the state and the provider ensure the best service and quality to the community.

\section{Conclusion}

The results of this study conclude that: 1) the best bureaucratic service in Southeast Asia is Singapore that implements a modern bureaucratic service oriented to

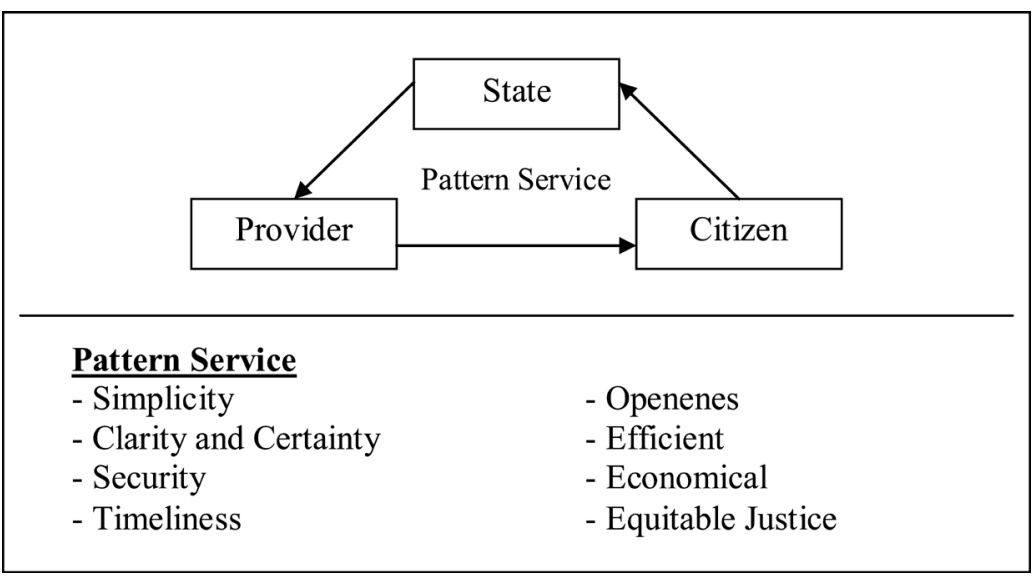

Source: Bureaucratic service implementation in Southeast Asian countries

Figure 6. Modern bureaucracy service development model. 
fun, pride and loyalty; 2) the effectiveness of government, new public management, new public service and modern bureaucracy service, is an important component needed in a state government; 3 ) modern bureaucratic service model is oriented to a simple, clear and secure pattern of service, safe, timely, open, efficient, economical and equitable justice.

\section{Recommendation}

Based on the results of research and theoretical thinking, this study recommends the need for Indonesia to consider applying new public management, new public service and modern bureaucracy service consistently, so that the country is present to provide services to the community according to the pattern of service which is simple, clear and sure, safe, precise time, open, efficient, economical and equitable. This service pattern is done according to system, strategy and management both with e-government method and e-company.

\section{Conflicts of Interest}

The author declares no conflicts of interest regarding the publication of this paper.

\section{References}

[1] Balley, M. (2006) The Administration Public System. Thompson Learning Press, USA.

[2] Keban, Y.T. (2004) Six Strategic Dimensions of Public Administration, Concepts, Theories and Issues. Gaya Media, Yogyakarta.

[3] Caldwen, D. (2012) Public Policy-Making Reexamined. Chandler Publishing Company, San Francisco.

[4] Robbinson (2012) Application of Quality Service Theory. John Wiley and Sons, New York.

[5] Osborne, D. (2008) Reinventing Government, Laboratories of Democracy. In: Keban, Y.T., Ed., Six Strategic Dimensions of Public Administration, Concepts, Theories and Issues, Gaya Media, Yogyakarta.

[6] Gaster, A.S. (2011) Measure Service Quality: Reexamination and Extension. Butterworth \& Heinemman, London.

[7] http://ejournalfia.ub.ac.id/index.php/jiap

[8] http://jurnal.unmer.ac.id/index.php/jkpp/article/view/426

[9] Hasard, W. (2012) The Administration Public Service: Serving, Not Steering. ANSI, New York. 